DOI: 10.14451/1.202.89

\title{
ПРОМЫШЛЕННАЯ ПОЛИТИКА РЕСПУБЛИКИ АРМЕНИЯ В КОНТЕКСТЕ ВЗАИМООТНОШЕНИЙ С ЕС И ЕАЭС
}

\section{(c) 2021 Даниэлян Артур Айказович}

соискатель, кафедра экономики и управления предприятиями и производственными комплексами Санкт-Петербургский государственный экономический университет, Россия, Санкт-Петербург

\author{
E-mail: Arthur_d@inbox.ru
}

В статье рассматриваются вопросы интеграции Республики Армения в международные экономические союзы. Дана характеристика промышленности Армении и показаны сравнительные преимущества и недостатки интеграции экономики Армении в Европейский союз и в Евразийский экономический союз.

Ключевые слова: Армения, интеграция промышленность, промышленная политика

Развитие экономики Республики Армения во многом определяется взаимоотношениями с Европейским Союзом (ЕС) и ЕАЭС, членом которого Армения является с 2015 года. Двусторонние отношения между ЕС и Арменией последовательно выстраивались в рамках изменчивой геополитической обстановки. Нужно отметить, что практически Армения начала взаимодействовать с ЕС в рамках Соглашения о всеобъемлющем и расширенном партнерстве (СЕРА), подписанного в ноябре 2017 года. Тем не менее, осталось много препятствий для более глубокого взаимодействия, что связано, в частности, с дистанцированием политики ЕС от граждан государства. Смысл в том, что обычные граждане определенных выгод от данного соглашения не получают (при проведении соответствующих опросов, примерно 46\% граждан Армении высказали это мнение), причем доверие к Европейскому Союзу продолжает снижаться, в том числе за счет достаточно жесткого навязывания формальных и неформальных правил ЕС, основанных на так называемых либеральных ценностях.

При этом, реализация ряда политических условий, за которые выступает ЕС, например, таких как демократические реформы, остается в какой-то степени проблематичной, поскольку их реализация не только зависит от политической воли действующего правительства, но может быть воспринята обычными гражданами как навязывание иностранных ценностей, что, во многих случаях, вызывает их отторжение. С этой точки зрения, помощь, которая может быть оказана Республике Армения в рамках соглашения СЕРА, ставится в зависимость от «советов»
ЕС, практически приравниваемых к обязательствам. В свете этого можно понять, почему реализация ряда политических условий, за которые выступает EC, например, таких как демократические реформы, проблематична, поскольку их реализация зависит не только от политической воли действующего на настоящий момент правительства, но и воспринимается как навязывание иностранных ценностей.

Можно предположить, что экономические меры сотрудничества как раз и могли бы принести определенную пользу. Республика Армения имеет определенные приоритеты, формализованные в Стратегии, в частности, одним из текущих приоритетов правительства является развитие индустрии туризма в Армении. В то же время, транспортное сообщение в настоящее время ограничено не только факторами, связанными с политическими аспектами (Карабахский конфликт, нестабильная политическая обстановка и др.), но и ценовым фактором на транспортные услуги.

Если говорить о преимуществах сотрудничества с ЕС и в рамках ЕАЭС в части расширения торговли, то необходимо рассмотреть экономическое положение Республики Армения, возможности развития тех или иных экспортоориентированных отраслей экономики и промышленности. Таким образом, мы приходим к необходимости оценки промышленной политики и ее влияния на экономику страны. На рис. 1 представлена динамика ВВП Республики Армения, начиная с 1992 года.

Как известно, промышленная политика может формулироваться с одной стороны, как система мер по развитию промышленности, со- 


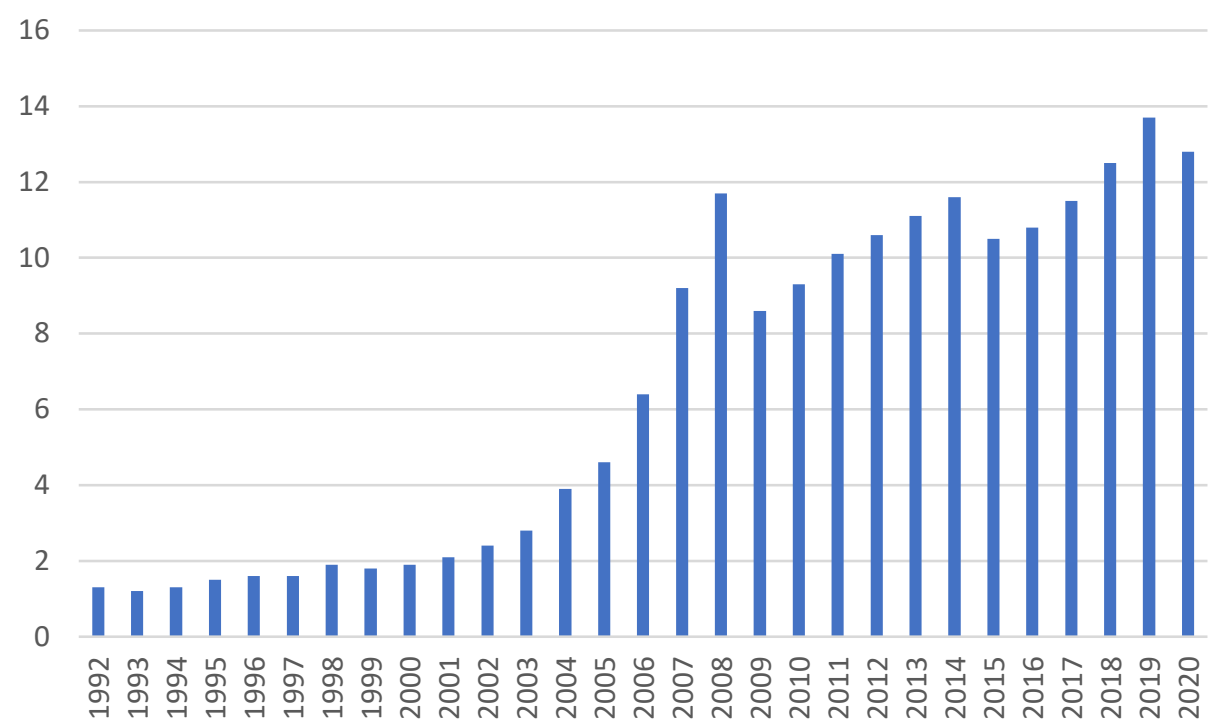

Рис.1. Динамика темпов изменения ВВП по отношению к предыдущему году, \% [1]

вершенствованию ее товарной и отраслевой структур на основе технологического развития производства [2]. С другой стороны, в более широком смысле, «национальная промышленная политика представляется как комплекс мер государственного регулирования экономических процессов на отраслевом и корпоративном уровне, направленный на стимулирование инновационной активности, структурной перестройки экономики и экономического роста» [3].

Промышленность была и остается основой развития экономики Республики Армения, будучи ее основной движущей. В советское время промышленность Армении была одной из самых развитых в СССР, в настоящее время промышленный сектор также считается одним из важнейших секторов экономики, хотя доля его с советских времен в ВВП Армении значительно сократилась (рис. 2) [4].

Сегодня Армения по структуре экономики продолжает оставаться аграрно-индустриальной страной. Основными отраслями промышленности в Армении традиционно были добыча полезных ископаемых и цветная металлургия, пищевая промышленность, фармакология, текстильная и ювелирная промышленность. В то же время, Армения, на наш взгляд, обладает огромным потенциалом в таких отраслях, как информационные технологии, легкая промышленность, химия, биотехнологии, машиностроение, приборостроение, электротехника и строительные материалы. Все эти отрасли (в том числе, реализующие потенциал обороннопромышленного комплекса) в определенной

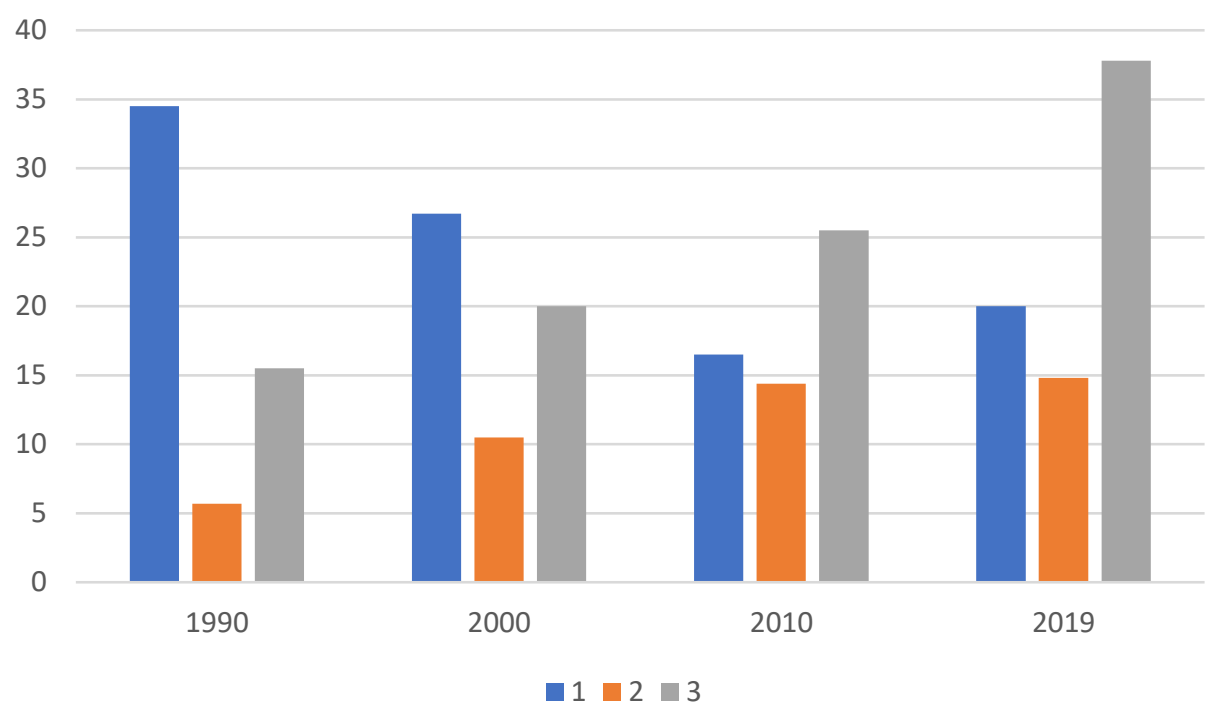

Рис.2 Динамика структуры ВВП Республики Армения (по отдельным отраслям экономики), \% 1- промышленность; 2 - торговля; 3 - услуги 
степени сохранились в республике и именно они будут определять ее развитие будущем. Особо хотелось обратить внимание на развитие военно-промышленного комплекса. Нужно отметить, что после распада СССР Россия получила в наследство около $80 \%$ оборонного потенциала, но на первых порах за счет собственных средств могла обеспечить только 17\% объема продукции военного назначения СССР [5]. Частично ряд предприятий ОПК бывших советских республик, в том числе и Армении, перешли в счет погашения государственного долга России, однако в настоящее время на территории Республики Армения функционирует около 30 высокотехнологичных оборонных предприятий, причем ориентация их та же, что и в советское время - разработка и производство элементной базы большей части связанных с разработкой и производством элементной базы, в том числе на основе советского задела по этому направлению, сформировавшего базу элементной промышленности Армении. В данном случае, можно подчеркнуть, что производство вооружений и военной техники не является приоритетным, но способствует развитию высокотехнологичных отраслей промышленности, успехи которой очевидны.

Тем не менее, Республика Армения, на наш взгляд, может получить ускоренное технологическое и промышленное развитие только в рамках международной интеграции, причем преимущественно в рамках ЕАЭС. Дело в том, что несмотря на определенное стремление к интеграции в рамках Европейского Союза, существует ряд экономических и политических барьеров на пути этого процесса. Прежде всего, экономика Республики Армения достаточно плотно связана с российской экономикой и экономикой стран-членов ЕАЭС, причем не только в рамках экспорта, где доминирующее место занимают Россия, Казахстан, Белоруссия. По данным Евразийской экономической комиссии, чистый приток прямых иностранных инвестиций в Армению в 2019 г. составил 254,5 млн. долл., при этом приток инвестиций из России составил 33,2 млн. долл. [6] В 2019 году чистый приток трансфертов частных лиц в Армении, по данным Центробанка, составил 504 миллиона долларов или 3,7\% ВВП [7]. В основном трансферты поступают от трудовых мигрантов в России. Частные трансферты за январь-март 2021 года по сравнению с тем же периодом прошлого года выросли на $47 \%$. Рост этого показателя за март 2021 года по сравнению с мартом 2020 года составил 145\% [8].

О значительной тесноте связей Республики Армения со странами ЕАЭС в области энергетики, и в первую очередь Россией, говорит и то, что 90\% объема поставок природного газа приходит из России, равно как и $100 \%$ ядерного топлива для Армянской АЭС.

Если учитывать основную цель развития Армении - построение экономики, основанной на знаниях и долгосрочную стратегическую задачу - развитие отраслей с экспортным потенциалом, сформированная промышленная политика может быть реализована наиболее эффективно, когда промышленные предприятия станут элементом интегрированных производственных цепочек, в рамках кооперации с предприятиями стран ЕАЭС. Еще одним доводом в пользу кооперации, позволяющей увеличить экспорт в страны ЕАЭС, является то, что малая емкость внутреннего рынка обуславливает экспортную направленность промышленности, соответственно рост объемов производства и снижение затрат за счет эффекта масштаба.

\section{Библиографический список}

1. ВВП в Армении рухнул в 2020 году | Экономика | Селдон Новости (myseldon.com); https://knoema.ru/atlas/ Армения/ВВП

2. Алахтаева Н.М. Стратегическое планирование, как механизм обеспечения промышленной политики субъекта Российской Федерации (на примере Республики Хакассия): Дис. ... канд. экон. наук: 08.00.05 Москва, 2000.

3. Смирнов Е. Инновационный вектор промышленной политики Европейского Союза // Международная экономика.2006. № $12-$ С.58

4. Экономика Армении, 1990-2019 (be5.biz)

5. Карлик А.Е., Фонтанель Ж. Оборонная промышленность России: развитие или упадок//Известия СанктПетербургского университета экономики и финансов.-2005-№ 4. С.35.

6. Основные тенденции интеграционного развития Армении в 2019 г. Евразийский банк развития. Дирекция по аналитической работе. 2020.C.18. https://eabr.org/upload/iblock/bc9/EABR_RA_06_2020_RU.pdf 
7. Пашинян: Армения зависит от денежных переводов из-за рубежа гораздо меньше, чем прежде. https:/ ru.armeniasputnik.am/20200406/Pashinyan-Armeniya-zavisit-ot-denezhnykh-perevodov-iz-za-rubezhagorazdo-menshe-chem-prezhde-22644371.html

8. ЦБ: Трансферты в Армению в первом квартале 2021 года выросли на 47\%, в марте - на 145\%. https://news. myseldon.com/ru/news/index/250220460 